Department of History of Architecture, Art and Technology,

Faculty of Architecture, Wrockaw University of Science and Technology

Wroctaw

roland.mruczek@pwr.edu.pl

ORCID ID: 0000-0003-1866-3147

ROLAND MRUCZEK

\title{
Medieval brick and stone timber framed houses - a missing link in the development of Silesian tenement house?
}

Abstract. Our study presents the most recent directions of research on the medieval burgher house in Silesia, looking at the issue through the prism of a certain house from Głogów, unique in the region, with a mixed brick and timber-framed structure with Steinwerk, which forces us to ask questions about the universality of this type of solutions - long absent in the panorama of large Silesian cities. A proposition of the typology of Silesian townhouses with a mixed structure, which was based on the results of research conducted by the author in Silesian cities in the years 1997-2018, was also presented.

Keywords: Silesia, Głogów, Middle Ages, archaeology, architecture, town, town/ tenement house, brick, timber-framed architecture.

\section{Introduction}

Recent years of research into the medieval and early modern city in Silesia (Śląsk), abounding in numerous surprising discoveries, make us revise many views, models and development schemes already established in literature. The enormous progress that was made in the research on the town house and the burgher tenement house primarily concerns the main settlement centres of the regions of Wrocław, Świdnica and Głogów (Chorowska 1994; 2010a; 2010b; Piekalski 1995; 2004; 2014; Jaworski 1999; Chorowska, Lasota 2003; 2013; Mruczek, Stefanowicz 2007; 2008; Mruczek 2010), although the significant advancement of research in other centers should also be emphasised, especially regarding Bolków, Brzeg, Dzierżoniów, Jawor, Legnica, Lwówek Śląski, Namysłów, Niemcza, Nysa, Oleśnica, Opole, Paczków, Polkowice, Sobótka, Strzegom, Strzelin, Środa Śląska, Ząbkowice Śląskie, Ziębice, Złotoryja, Żagań or the neighborhood Łużyce Żary (Gliński 2013; 
Mruczek 2019a). Extremely large groups of houses in Wrocław, Głogów and Świdnica became the subject of analyses concerning not only subdivision, typology of spatial-functional systems, or chronology of individual construction phases, but first of all, various developmental regularities, especially the parallel functioning of economically different implementation standards, which drew attention to the multi-aspect character and huge dynamics of the evolution of the burgher tenement house in Silesia ${ }^{1}$.

\section{The elitism of the Wroclaw burgher tenement house and the diversity of construction solutions for urban and rural medieval architecture in Silesia}

Medieval residential architecture researchers who were accustomed to the exceptionally early chronology, high standard and rapid spread of the brick house in Wrocław - while noticing the 'western', Town Charter character of the phenomenon - treated its appearance in the panorama of the early city as an 'import' and a qualitative change and initially they did not pay much attention to the issue of potential connections with, for example wooden architecture, both local - log (corner timbering) and mixed posts-corner timbered-framework construction (Upper Lusatian House structures; Ger. Umbeginde), as well as timber framed architecture which was brought by foreign hospites. This approach was also partly due to the traditional division of research competences between archaeologists and architectural historians, which was especially pronounced in the case of the dynamic settlement phenomena of the $13^{\text {th }}$ century. Even a huge increase in the knowledge about wooden buildings and infrastructure of Ostrów Tumski, especially the so-called of Nowy

${ }^{1}$ Our study used, inter alia, the results of a wide-ranging archaeological and architectural research conducted by the author in the years 1997-2018 in the area of over twenty quarters of bourgeois development in the Old Town complexes of Wrocław and Głogów (reconstruction of the Old Town after the destruction of World War II) as well as smaller complexes of the old town development of Polkowice, Sobótka, Środa Śląska or Żary. The research was conducted as part of the Consortium of the Archaeological and Historical Museum in Głogów and the Akme - Zdzisław Wiśniewski company in Wrocław, under the substantive supervision of employees of the Institute of History of Architecture, Art and Technology (Faculty of Architecture, Wrocław University of Technology), Professor Jerzy Rozpędowski, Professor Małgorzata Chorowska, Doctor Czesław Lasota and the author (research management since 2000). The research concerned both cubature objects - existing and in use, as well as architectural relics of cellars of buildings destroyed as a result of warfare. During the works, the remains of several hundred town houses and town houses were examined. The research was carried out using both the excavation method and the method of architectural surveys, making a detailed inventory and chronological stratification based on a stratigraphic analysis and analysis of construction techniques and technology, also with the use of laboratory analyses of mortars and statistical analyses of bricks (Mruczek 2019b). The state of research on a burgher tenement house and a town house in Silesia - along with extensive literature on the subject - is summarised in the work (Mruczek 2019a) and the issues of Głogów research are outlined in the work (Mruczek 2010). A comprehensive study of the research results is currently being prepared. 
Targ settlement on the left bank of the Odra River (Kaźmierczyk 1966; 1970; 1991; 1993; 1995; Niegoda 2005) - despite the presence of 'foreign' timber-framed structures and brick houses with a spatial disposition different than in the market zone - initially did not influence the change in the research optics. The breakthrough was the research into the Wrocław Market Square (Rynek Wrocławski 1 2001; Rynek Wroctawski 2 2002), as well as studies on two full-curia plots in the eastern block of building development near the market square, annexed already in the middle of the $13^{\text {th }}$ century for the needs of Kurzy Targ Street (Mruczek 2000). It was a unique opportunity to examine the four-meter-thick archaeological layers of the original burgher plots, which have never had brick buildings. The discovery of the relics of timber-framed burgher houses (dendrochronologically dated for years: after 1209-after 1230), on which layers of the subsequent phases of wooden track-bridges of Kurzy Targ Street (after 1258-after 1263), contributed to the revival of the discussion on the early chronology of the Wrocław Market Square and the issue of urban changes from before 1241. At the same time, it showed the unexpectedly high dynamics of settlement processes in the first decades of the town's existence and made Wrocław researchers aware of the problem of a huge gap in the stratigraphy which was caused by the dynamic introduction of brick buildings in the second quarter of the $13^{\text {th }}$ century, which by the end of the $14^{\text {th }}$ century led to the complete destruction of older relics of development in the front parts of burgher plots.

The fact that between the timber-framed house and the burgher tenement house there could have existed the whole range of transitional forms, which we have not been able to recognise so far, is proved by the discoveries, which were made in the subsequent years, of the $13^{\text {th }}$-century detached brick (self-supporting) cellars resembling stone solutions of this type, which appeared on a mass scale as an element of extensive multi-storey timber-framed houses in Świdnica in the years 1250-1380 (Chorowska, Lasota 2013). In Wrocław, they were identified, for example, on a plot at 60 Rynek, where such a basement preceded the construction of a brick front house from the $13^{\text {th }}$ century; under Oławska Street, where it was largely destroyed during the construction of the tower of Oławska Gate in the $2^{\text {nd }}$ and $3^{\text {rd }}$ third part of the $13^{\text {th }}$ century; within the Wrocław mid-market block, in Garncarskie Przejście Street, where its perimeter walls are sunk directly into the sand bed; at 40 Nowa Street, in the vicinity of the outer defensive walls and the non-existing city gate, and at 25 Wierzbowa Street, near the quarters of Walonów and Słodowników (Limisiewicz, Mruczek 2010, pp. 90-97). The chronology of the oldest objects of this type in Wrocław certainly dates back to the $2^{\text {nd }}$ quarter of the $13^{\text {th }}$ century and the end of their occurrence in peripheral areas is not determined until the $18^{\text {th }}$ century. We also know numerous examples of similar structures from Głogów, Polkowice or Środa Śląska, where they functioned from the late Middle Ages until the times of Frederick the Great's colonization in the 1770s (Ciara et al. 2003; Mruczek 2019a, pp. 57, 59). 
Parallel long-term studies on historic rural buildings in the Sudetes region (Trocka-Leszczyńska 1995) - which represented extremely diverse, usually mixed structural solutions, combining the achievements of the medieval log, timberframed and Upper Lusatian House construction with brick structures, coincided with the revival of research on small location centres, where archaeological remains of buildings of a definitely 'non-urban' character began to be noticed (Guszpit et al. 2002; Limisiewicz, Mruczek 2001). Huge progress was also made in the field of research into residential and defence architecture in Silesia (Chorowska 2003; Boguszewicz 2010). Their results made it possible not only to show the European origins of huge construction investments of Silesian feudal lords, but above all to emphasise many of their individual features of a regional character. An unquestionable breakthrough in the field of research on late-medieval log and brick structures was the discovery of negatives of a wooden structure on an octagonal plan, constituting the core of the brick perimeter walls of an octagonal donjon-type tower with a sharp edge of Niesytno Castle in Płonina (15 ${ }^{\text {th }}$ century; Chorowska 2003; Chorowska, Błoniewski 2013). The structural role of the wooden wreath distinguishes this tower from the group of layouts with the so-called warm rooms, where the wood used constitutes rather insulating cladding (Siedlęcin, Radłówka, Szczerba in Gniewoszów). Of course, attempts to solidify building walls with longitudinal and transverse wooden beams have a much earlier tradition in Silesia, just to mention only the examples of the hillfort church from Głogów (12 ${ }^{\text {th }}$ century) or the six-sided tower of the bergfried type of the castle in Wlen $\left(12^{\text {th }} / 13^{\text {th }}\right.$ centuries $)$ and they are also in the early modern times, such as in the curtains of the roundel fortifications in Wrocław $\left(15^{\text {th }} / 16^{\text {th }}\right.$ centuries), however, they never took such a spectacular form (Kozaczewski 2006, pp. 34-36, Figs. 13-15; Mruczek 2005; 2018; 2019b; Mruczek, Stefanowicz 2010, pp. 426-431, Figs. 8-11).

Unexpectedly, in autumn 2004, new research perspectives were opened by the discovery of the almost entirely preserved part of the basement of the corner house at the intersection of Balwierska and Garncarska Streets in the Old Town in Głogów, which is unique in Silesia (Figs. 1, 2). It was a two-section layout within the ground floor with a hall and passage, with a full basement, a front of which was made of mixed brick-timber-framed structure (with brick perimeter walls made in the Wendish (Slavonic) bond, covering and filling the wooden frame), covered with a ceiling, with cellars under a much more solidly constructed back section (Steinwerk?), a walkway and an additional one which was separated from the front tract - with a barrel vault and at least partly timber-framed storeys above ground. The connection between the ground floor and the basement was probably organised by means of a ramp for rolling barrels accessible from the entryway, located in the first two parts above the back basement and in the third one under the passage. The front cellar was also accessible by means of steep stairs directly from the front, i.e. from Garncarska Street. Due to a significant distance of the front 

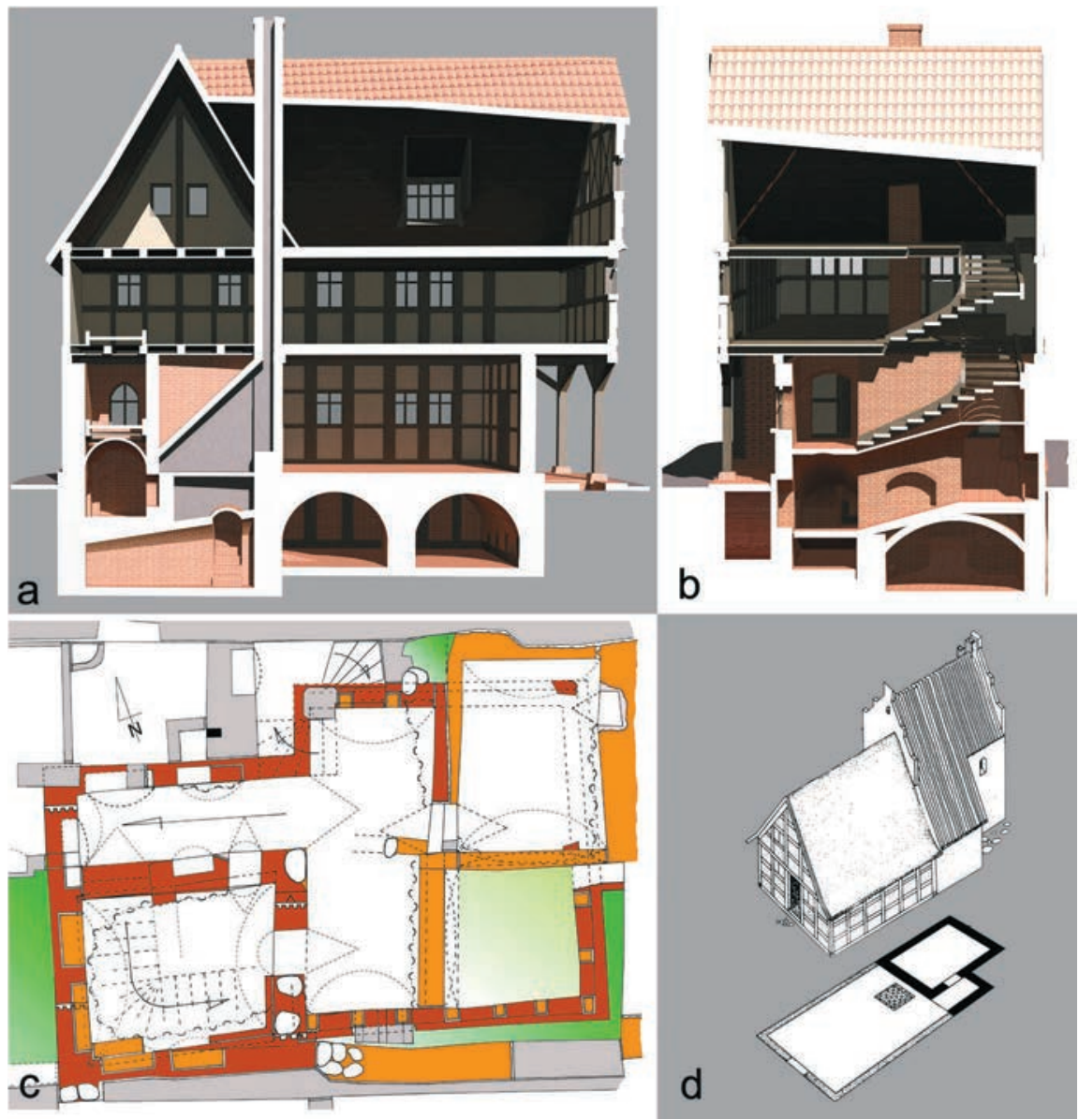

Fig. 1. Głogów, Old Town. A brick-frame house with Steinwerk at the intersection of Balwierska and Garncarska Streets (square A23); $15^{\text {th }}$ century: a - reconstruction attempt, longitudinal section; b - reconstruction attempt, cross-section; $\mathrm{c}$ - chronological breakdown (phasing); d - Riga, a frame house with Steinwerk (a-c-measurement, chronological stratification, spatial-functional reconstruction: R. Mruczek, M. Stefanowicz; visualization and 3D modeling: M. Caban; d - after Piekalski 2004 with author's corrections)

wall of the building from the front of the plot, it can be assumed with high probability that it originally had a porch or an arcade similar in structure to the solutions that no longer exist today, known from Bolków, Środa Śląska or Świebodzin, and preserved in modern houses from Sulików (Mruczek, Stefanowicz 2007; Mruczek 2010, pp. 178-179, Fig. XIII; 2019a, pp. 59-60, Fig. 4). This building completely departs from the Świdnica model of a house, which was reconstructed 

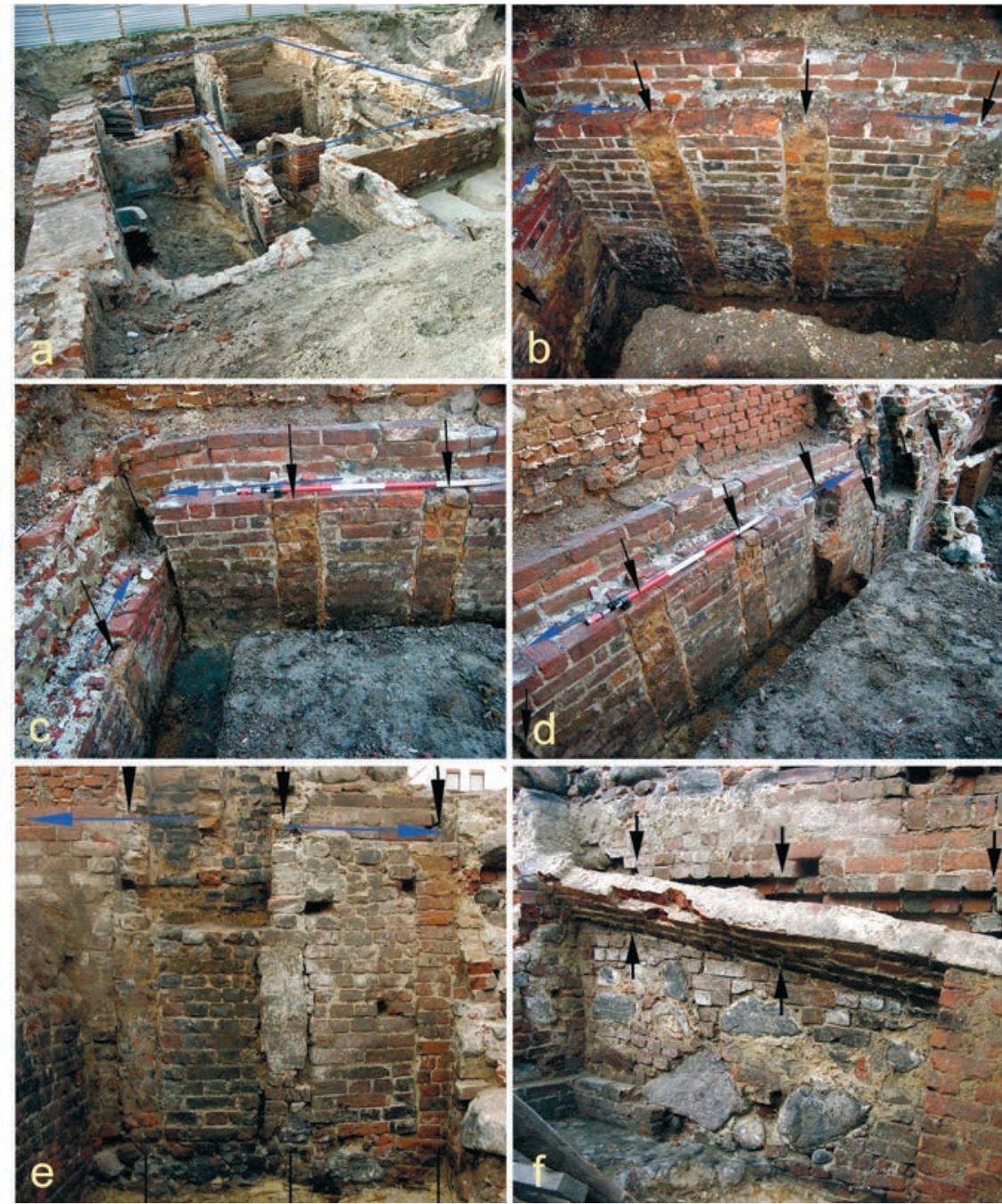

Fig. 2. Głogów, Old Town. A brick-frame house with Steinwerk at the intersection of Balwierska and Garncarska Streets (square A23); $15^{\text {th }}$ century: a - general view of the relics from the SE; b-e - perimeter walls of the basement of the front tract (black arrows mark the bricked up negatives of columns, blue arrows the course of the cap; $\mathrm{f}$ - the vault of the basement of the back track, taken from the offset with an overhang (photo by R. Mruczek, M. Stefanowicz)

by researchers, with a detached brick basement (usually self-supported, barrel vaulted), over which an extensive timber-framed building or of a mixed structure was erected - commonly regarded as an intermediate link in the development of the Silesian tenement house. Thus, it constitutes at least potentially an element of the alternative parallel development sequence of Silesian town houses, 
which derived directly from the experiences of the $13^{\text {th }}$-century wattle and daub structures, which would be merged with the brick construction technique. Once again, the survival of the relics of this extraordinary building was determined by completely unique in the scale of Głogów circumstances of abandoning and filling in its remains during the construction of the $19^{\text {th }}$-century tenement house ${ }^{2}$.

The above discoveries undoubtedly enrich the image of the medieval town house in Silesia, which is already well-established in literature - and due to its uniqueness - force us to pose the question that is in the title of our study. Are we dealing, then, with a phenomenon, an individual case confirming the parallel functioning of many different implementation standards, or should we rather see a missing lost link in it - a representative of a once more numerous group of objects? What would be the place of these buildings in the evolutionary course of burgher architecture in Silesia? Could such a form appear immediately in its final shape as early as in the $13^{\text {th }}$ century - simultaneously with timber-framed and brick houses ${ }^{3}$, or is it the result of later experiments mainly on an economic basis, rather typical of construction actions undertaken at the end of the Middle Ages in smaller local centres? The argument of exceptional circumstances of the discovery raised earlier allows us to draw cautious conclusions that they were not isolated buildings in terms of structural solutions, and their insignificant frequency - despite researching huge areas of the Old Town centres of Wrocław and Głogów - resulted only from the rapid development of brick buildings in Silesian cities in the late Middle Ages, which completely destroyed the evidence of previous construction actions. This process, in Wrocław dated for as early as the $2^{\text {nd }}$ half of the $13^{\text {th }}$ and $14^{\text {th }}$ centuries,

${ }^{2}$ In the reality of Wrocław, the existence of spaces without a basement under the old tenement houses within the inner ring of the defensive walls is a completely unique phenomenon. It is necessary to mention the case of a gothic tenement house at 6 Krawiecka Street, which absorbed a fragment of the nameless passage on the extension of Kaznodziejska Street, which lead from the market zone towards the so-called The Suburbs of St. Maurycy (Mauritius) and adapted it to the needs of the entryway. Archaeological works undertaken within it revealed, inter alia, relics of a pre-location, early medieval cemetery belt (Limisiewicz, Mruczek 2010, pp. 85-87).

3 A similar structure of internal divisions of the basement of the tenement house at 12 . Ratuszowa Street in Kołobrzeg is dated by the authors of the research at the earliest for the second half of the $14^{\text {th }}$ century (Polak, Rębkowski 1996, pp. 213, 215, Fig. IV-5). We know an example closer to the Głogów construction from the research of the Old Town in Elbląg, where at VIIIa/531$\mathrm{VIIIb} / 530$ św. Ducha Street, relics of the skeleton and brick basement wall of the tenement house dating back to the end of the $14^{\text {th }}$ century or the beginning of the $15^{\text {th }}$ century were discovered (Kąsinowski 1992, pp. 67-78, Tafel 10.2). In the upper stories of houses, similar solutions are found, inter alia, in Torun in Garbary Street and Cahors (Midi-Pyrénées/France), 46 rue Donzelle. It is impossible to prejudge the relationship with such structures of the $13^{\text {th }}$-century archaeological layers at 2 Ruska Street in Wrocław. Looking at the example of one of the houses in Głogów in Kotlarska Street, the oldest brick object on the plot could have been a hypocaustum type stove. On the other hand, we know a modern wall with a similar structure, with bricked up negatives of massive columns, from the non-existent now relics of the Mill in Kępa Mieszczańska (formerly within the Młyńska Island) in Wrocław, which were studied by the author in 2016. 
in the case of small foundations, accelerated only at the turn of the $16^{\text {th }}$ century ${ }^{4}$. Therefore, it seems obvious that in the face of the constant risk of fire, the art of constructing timber-framed houses or using this structure had to be constantly developed in Silesian towns. This still poorly known face of bourgeois architecture, which is only heralded by the discoveries in Głogów, may reveal future archaeological research of small settlement centres, especially those located in the brick construction zone in the northern regions of the Silesian Lowlands (Niż Śląski) and Lubusz Land (ziemia lubuska). This study attempts at showing the structural and material diversity of medieval Silesian houses with particular emphasis on the usually overlooked elements of timber-framed structures, on the basis of the research results concerning Wrocław, Głogów, Polkowice, Sobótka and Świdnica.

\section{Structural and material diversity of Silesian burgher houses in the Middle Ages in terms of chronology, topography and economy}

\section{Timber-framed houses}

One of the manifestations of the breakthrough in terms of town foundation in Silesia was the appearance of new construction solutions in the field of residential construction, which were connected with the arrival of Western hospites. Contrary to the traditional early medieval structures which were known from Ostrów Tumski and early left-bank settlements, i.e. log, wattle and daub, palisade or wattle, the original development of bourgeois plots in the $13^{\text {th }}$-century Wrocław was predominantly of timber-framed character (Kaźmierczyk 1966; 1970, pp. 52-55, 58; 1991; 1993; 1995; Chorowska 1994, pp. 79-80; 2011, pp. 49-50; Chorowska et al. 2012; Jaworski 1999; Piekalski 1996; 2004; 2014, pp. 154-160; Niegoda 2005). Such constructions provided significant material savings and offered the possibility to erect at least two-storey buildings, which was a revolutionary change in the town's panorama. In the case of Wrocław, this qualitative leap can be seen most clearly in the market zone, where the enormous dynamics of settlement changes in the first decades after the location is illustrated by the two-three-meter-thick sequences of archaeological layers, among which the destructed fragments of subsequent wattle and daub buildings destroyed by fires (1241?, 1254) or dismantled due to the increasing level of use are especially noteworthy. The main structural levels in Kurzy Targ are dated for 1209-after 1230, and the re-regulation of this part of the town took place in the years 1254-1263. The intense and older settlement of this zone is indirectly dated by huge beams which were reused as foundations in buildings discovered near the adjacent St. Maria Magdalena Parish Church, from which dates after 1185, two after 1202,

${ }^{4}$ For example, in the founding Chojnów, only three stone houses were recorded in 1533 (out of 251 houses within the defensive walls, mentioned in 1553), and in the nearby Świerzawa, the oldest known tone house was supposed to be built in 1690 (Kozak, Steinborn 1971, pp. 70, 111). 
after 1215 and after 1234 were obtained. They probably came from the demolition of the original temple of the settlement of German guests, then replaced by another archaeologically confirmed layout of a town parish character, which was in use as early as 1226 , completed and fenced together with the cemetery after 1239 . Numerous relics of buildings erected in a post interrupted sill construction are found there (Piekalski 1995, pp. 75-87; 2004, pp. 174-176; 2014, pp. 153-154; Mruczek 2000, pp. 259-278; Kitliński 2002, p. 276; Limisiewicz, Mruczek 2010, p. 125). The most common, however, are timber framing solutions, based on a system of foundations and pillars connected in a Tyrolean knot, with clay filling of walls supported by wattle and daub (Fig. 3). Examples of decorating such walls with a stylized embossed floral ornament, maintained in the late-Romanesque style, common in the $2^{\text {nd }}$ quarter of the $13^{\text {th }}$ century and discovered on the secondary deposit at 8 Igielna Street are intriguing (Piekalski 1995, pp. 79-80, Fig. 5, photo 1). The original, $13^{\text {th }}$-century front houses with timber-framed structures were dismantled yet in the Middle Ages and today only fire layers consisting of the so-called wattle and daub debris and few structural elements found in the secondary deposit can testify to their existence. Also, the cultural layers connected with them were almost $100 \%$ destroyed during the digging of basements of brick houses. The situation is different in the rear parts of the plots, where the archaeological stratigraphy was not disturbed to such an extent. The farm buildings discovered there represented various types of timber-framed structures which were based on a system of foundations, pillars, beams and struts, fastened with a pile cap, filled with wattle and daub, plait lines and thin clay, often with planks.

2. Houses with a mixed structure of perimeter walls. They existed throughout the Middle Ages in various variants

2a. Houses with brick cellars and above-ground timber-framed parts. This group includes:

2a1. Timber-framed houses with self-supporting (detached) cellars - structurally independent;

2a2. Timber-framed houses with structurally integrated cellars.

The first variant is certainly the most characteristic feature of the early bourgeois architecture of Świdnica - the second largest late medieval urban centre in Silesia. Extremely numerous stone objects of this type with characteristic ramps for rolling barrels, which occur especially in the market zone and lead to the line of the $14^{\text {th }}$-century development, are dated for the years $1250-1380$ by researchers (Chorowska, Lasota 2003, p. 44; 2013, pp. 10-15, 36-37, Figs. 19, 66-74, 202, 206; Chorowska 2010a, pp. 348-352, 356-360, Fig. 7). Structurally independent extensive timber-framed layouts with arcades were constructed above them. The presence of similar cellars, both stone and brick, was also found during research in Wrocław, Głogów, Środa Śląska and Polkowice. 


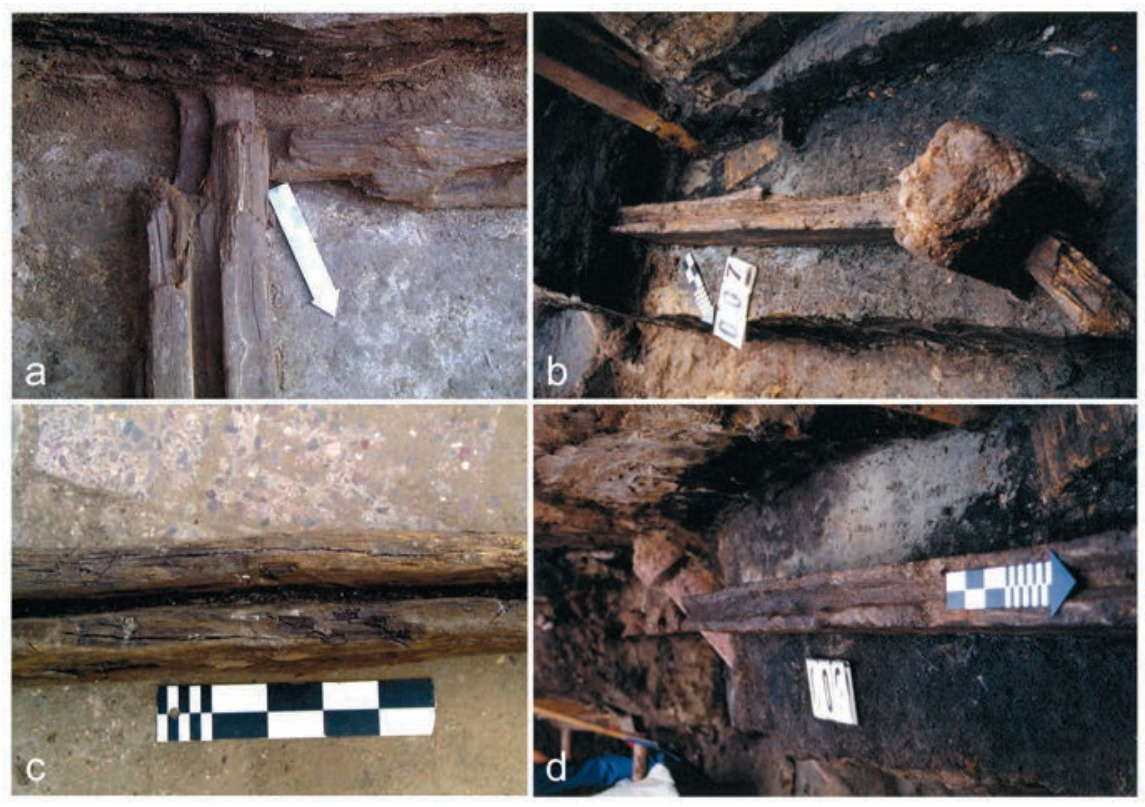

Fig. 3. Wrocław, Old Town. Relics of the $13^{\text {th }}$ century frame structures: a - Kurzy Targ Street; the corner of the building in a frame-and-column structure, dendrochronologically dated back to $1230 ; \mathrm{b}, \mathrm{d}-\mathrm{St}$. Mary Magdalene Street; the relics of the fence of post building in interrupted sill construction, dendrochronologically dated back to 1239 ; c - Kurzy Targ Street; obtained on a secondary deposit in the thirteenth-century strata, the so-called interrupted sill (photo by R. Mruczek)

In Wrocław, this type of development is not represented in large numbers today. An almost complete self-supporting cellar was identified in 2008 on a plot at 60 Rynek, where it was immediately preceded by the construction of a brick front house with a stoop, which dates back to the $13^{\text {th }}$ century, creating a characteristic fault in its northern perimeter wall (Fig. 4: a) (Limisiewicz, Mruczek 2010, pp. 90, 92, Figs. 11, 125-126). It was an entirely brick structure with foundations which were constructed deeply in natural sand with a Wendish bond and covered with a barrel supported by shield walls. Due to the fact that plot number 60, as the only one on Wrocław Market Square, retained its original full-size curia dimensions of $60 \times 120$ feet and the eastern wall of this basement basically coincided with the theoretically measured border with the neighboring plot number 59, it would be one of the oldest examples of construction initiatives of Wrocław burghers. However, this conclusion could raise considerable doubts, if we get familiar with the circumstances of the discovery in 2005 of a similar detached brick cellar under Oławska Street (Fig. 4: b). It was destroyed to a large extent during the construction of the tower of Oława Gate I, in the $2^{\text {nd }}$ and $3^{\text {rd }}$ thirds of the $13^{\text {th }}$ century. It was located diagonally in relation to 
the $13^{\text {th }}$-century subdivision network and additionally in the zone of the main street leading east of the city, and could have been a remnant of one of the settlements of the former Wrocław agglomeration, perhaps the so-called Walloon settlement, the settlement at St. Mary the Egyptian Church or one of the curiae mentioned in 1226, which were located in the vicinity of St. Wojciech Church, although its connection with the alleged earlier fortifications in this place cannot be ruled out either (Limisiewicz, Mruczek 2010, pp. 90-91, Figs. 10, 125-126; Piekalski 2014, p. 72). Another relic of a basement of this type, which was constructed directly on natural sand soil, was found within the Wrocław block of inter-market, in Przejście Garncarskie Street. For a change, the monument, which was discovered at 25 Wierzbowa Street, in the vicinity of the border between the quarters of Walonów and Słodowników, has a much later modern origin. Its possible connection with the so-called Scholz Gardens (1587/1588-1599) needs to be researched. In turn, the object known from the plot at 40 Nowa Street - despite the similarity of the basement itself - due to structural differences, will be discussed in the next subgroup. A small percentage of the self-supporting cellars discovered so far in Wrocław can be explained by the fact that they were destroyed in the course of further development. Both the very early chronology of the oldest Wrocław solutions and the long existence of this model until modern times is undisputable.

Among the relatively numerous examples from Głogów ${ }^{5}$, we should pay attention to the house at 8 Długa Street (quarter A15/A16) or 11 Polska Street (quarter A10) - both from phase II (Fig. 4: c, d) - but also a modern house at 1 Młyńska Street (quarter A10). On this basis, it is difficult to judge with certainty that this is a structural solution characteristic of the poorer parts of the Old Town, nevertheless, in such districts it had a much greater chance of surviving in the course of further development, as we are sometimes convinced by very ingenious and breakneck adaptations of such structures in later buildings. The chronology of these cellars, which was determined by the analysis of construction techniques and technology, covers the late Middle Ages (phases I-II). What is certain, however, was the 'long duration' of these solutions which were easy and cheap to construct. The youngest examples of them from Głogów can be connected with the period of reconstruction after the Thirty Years'War ( $2^{\text {nd }}$ half of the $17^{\text {th }}$ century), as well as similar structures from Polkowice, Prusice or Środa Śląska, which were superseded only by the 'Frederick' construction or the $19^{\text {th }}$ century construction boom.

The second variant, in the light of excavations in the Old Town in Głogów, must have had quite numerous elements initially, although it is currently hardly available to researchers. It is very difficult to establish unambiguous criteria for its recognition in field practice. The presence of timber-framed houses above brick cellars could be irrefutably confirmed only by the negatives of the insulated

${ }^{5}$ In this study, the numbering of Głogów houses refers to the temporary numbering of plots, which was adopted during the excavation works in the years 2000-2007. 

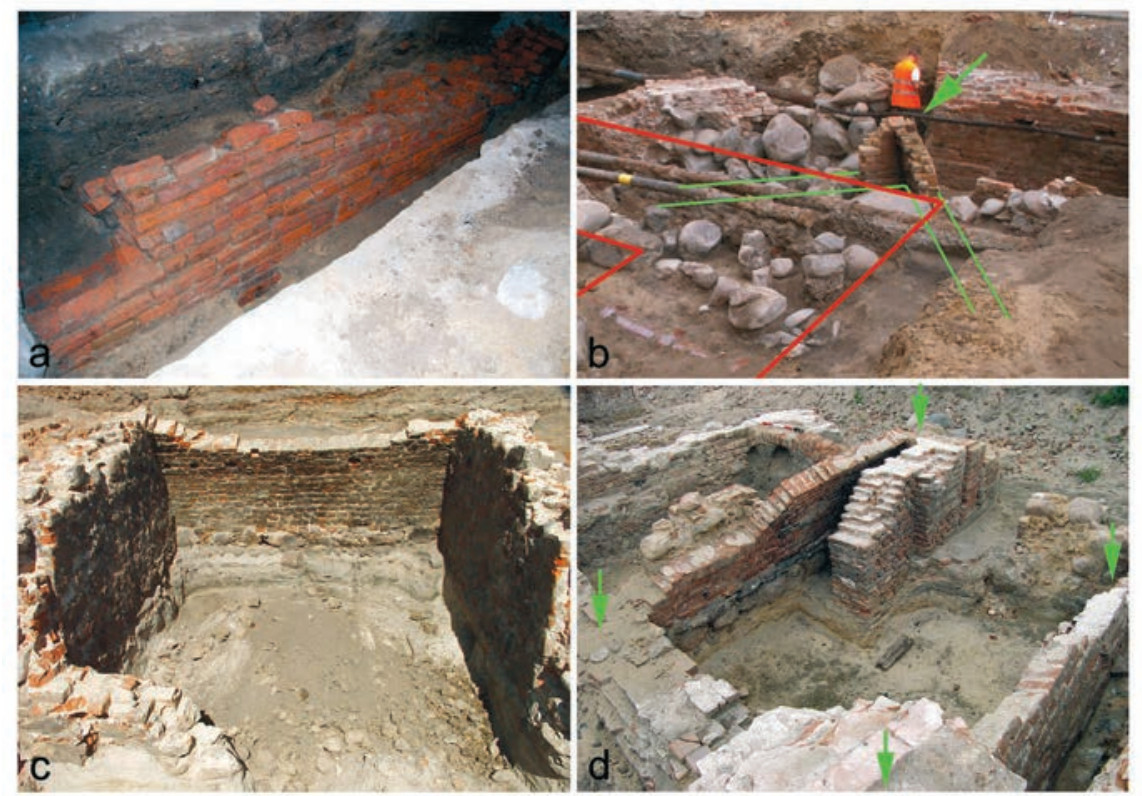

Fig. 4. Relics of free-standing cellars under half-timbered buildings $\left(13^{\text {th }}-15^{\text {th }}\right.$ centuries): a - Wrocław, Old Town. Tenement House Rynek 60. Self-supporting cellar, preceding the erection of the tenement house from the $13^{\text {th }}$ century; b - Wrocław, Old Town. Oławska Gate I. Corner of the self-supporting cellar, destroyed during the construction of the town gate in the second half of the $13^{\text {th }}$ century; c - Głogów, Old Town. Self-supporting cellar at 11 Polska Street (quarter A10), adapted during the construction of the tenement house in the late Middle Ages; d - Głogów, Old Town. Self-supporting cellar at 8 Długa Street (quarter A15-A16), adapted during the construction of the tenement house in the late Middle Ages ( $\mathrm{a}$ - photo by T. Kastek, b-d - photo by R. Mruczek)

foundations and pillars which made up the ground floor structure. However, these are missing, and the conspicuous screed seems to testify that the crowns of the walls were first carefully leveled. Identical conclusions can be drawn from the research on the foundations parts of Salvator Church in Wrocław, which was built in several phases in the $2^{\text {nd }}$ half of the $16^{\text {th }}-18^{\text {th }}$ centuries (Guszpit et al. 2015), and where the reconstruction of the above-ground parts was necessarily carried out solely on the basis of the analysis of iconography (Caban 2015). In the course of the research carried out in Głogów, the negatives of pillars (dowels?) with small cross-sections were found. They were located in the places of perimeter walls which was significant form the constructional point of view. Presumably, these are traces of anchoring the foundations.

An important criterion, which would be helpful in the search for this type of buildings, could also be the specific, 'economical' structure of perimeter walls, 
which was supported by pillar-arch walls, with immediately filled sub-arches in order to build a basement for the house. Here, however, there is a difficulty in distinguishing typical neighborhood (border) walls, which were also built of brick in their higher parts, from arcaded foundation walls. The house at 2 Słodowa Street from phase I (Gothic/14 ${ }^{\text {th }}$ century), which is protruding along with the neighboring houses (numbers 1-5; quarter A15/A16) into the public zone of the street in a characteristic way, is extremely interesting for our analysis (Fig. 5) (Burnita et al. 2000). The neighboring corner house at the intersection of Słodowa (number 1) and Kotlarska Streets was certainly made of brick from the very beginning. This is evidenced not only by the massive stone and brick ridge walls, but also by the walls of stoops (arcade with the basement?), as well as front, inter-plot and rear walls. It is worth noticing that the front wall of the house number 1 coincides with the 'retracted' line of the northern frontage development of the street in phase II (late Gothic $/ 2^{\text {nd }}$ half of the $15^{\text {th }} / 1^{\text {st }}$ half of the $16^{\text {th }}$ century). This probably means that the actual line of the development, which was marked by the fronts of the oldest $14^{\text {th }}$-century buildings, was the same from the beginning and the protruding of the fronts at the basement level was related only to the stoops or arcades with basements. This is of key importance for the reconstruction of the tenement house at 2 Słodowa Street from phase I. If it were in fact a brick house from the beginning, its front would have to be supported by a structurally not very strong asymmetrical arcaded wall, significantly protruding into the public space of the street. No other intermediate supports were found, for example in the form of an arcade wall similar to Świdnica houses from phase II (Chorowska, Lasota 2013), on which an alternatively located front wall could be based and formed on the extension of the actual development line. Such a significant protrusion of the brick building into the street space would have also prevented transport along the alleged arcades in the northern frontage of Słodowa Street. The most likely solution there seems to be the functioning of a house with a timber-framed structure of the above-ground parts along with a stoop or an arcade based on a foundation wall protruding into the street space and a front wall supported on pillars and neighboring walls, constituting an extension of the front of house number 1 and thus the line of development on the northern frontage of Słodowa Street in phase II. The cellars of the house number 2 in phase I were covered with a ceiling. The puzzling distribution of beam nests formed in the western (neighborhood) boundary wall - grouped in its northern part with their complete absence at this level in the southern part, constitutes an additional argument for the existence of a significant interior division in this place. The structure of the alleged timber-framed front wall would have rested on the one side of the western end of the front wall of the house (number 1) and on the other side on the central pillar of the neighboring wall of houses numbers 2 and 3. For obvious reasons, the ceiling in the southern part of the basement, which corresponded to the stoop or the arcade, was much higher, so there were no visible traces in the form 


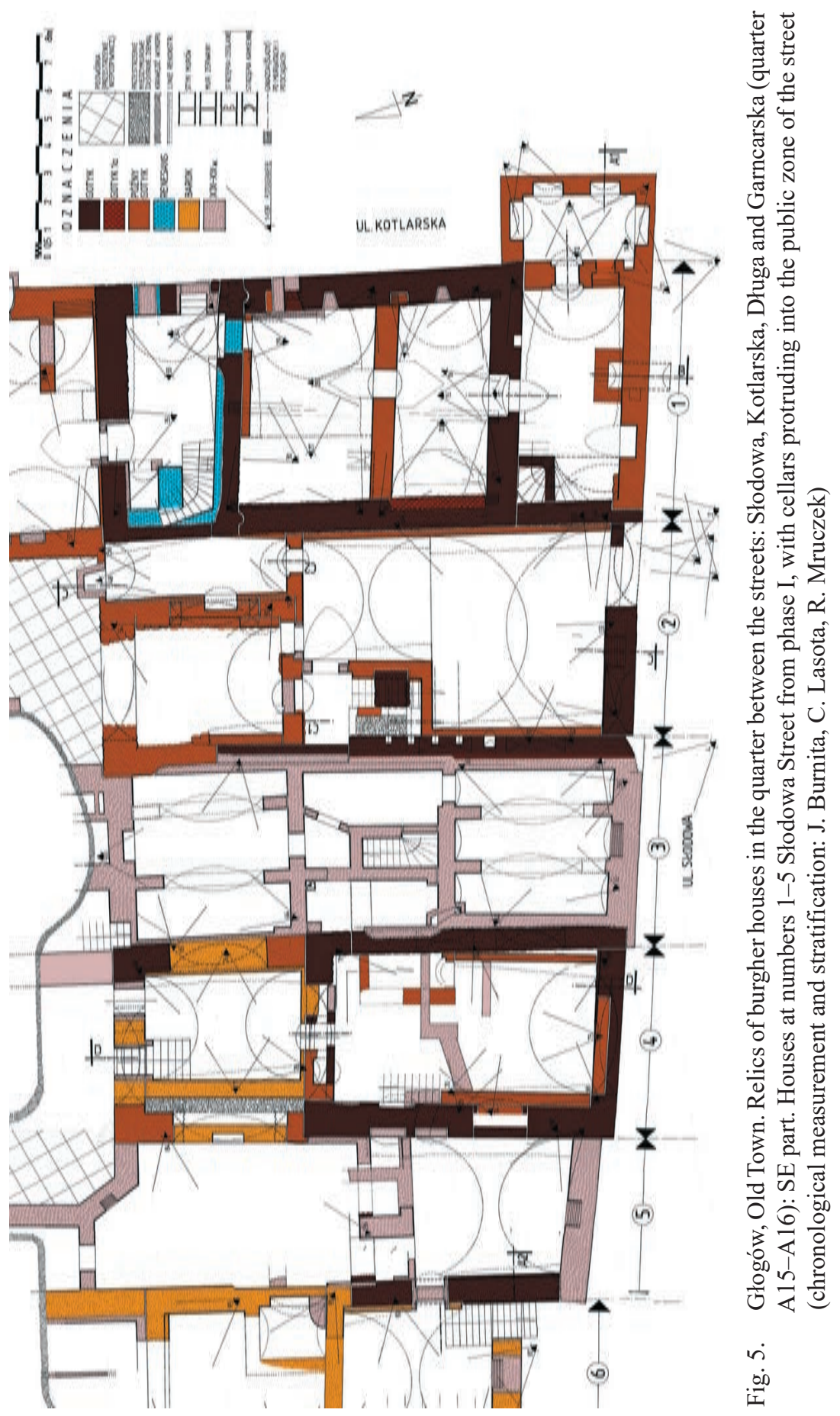


of nests or wall plates. The timber-framed house at 2 Słodowa Street from phase I disappeared as a result of major remodeling which was carried out in phase II. Paradoxically, a new protruding line of the development of houses numbers $1-5$, in force until 1945, was established. It was different from the one marked by the fronts of houses numbers 6-10, which were built from scratch in phase II.

The very modest late medieval house in Wrocław at 40 Nowa Street - located at the highest point of the so-called Kacerska Górka (Ketzerberg), in the vicinity of the outer defensive walls and the non-existing city gate looks completely different (Chorowska, Kwaśniewski 2000; Limisiewicz, Mruczek 2010, pp. 96-97). Its basement part, which was deeply set in the natural sand ground, consisted of a rectangular outline of arcaded perimeter walls and a barrel vault stretched directly on the berms which were formed in the faces of pillars. This not too massive structure could only support a modest timber-framed building. In the realities of Wrocław and Głogów, this solution - typical of poorer bourgeois quarters - is relatively rare. On the other hand, the simplest layouts of timber-framed houses with stone and stone-brick cellars can be found in Polkowice, both in the location area and in the suburbs. Terminus ante quem of their construction is determined by the great reconstruction of the city in the Frederick era (1772-1775). The relics of these layouts were recorded, inter alia, on plots at 1 Gdańska and 4 Górna Streets (Ciara et al. 2003, pp. 208, 213-215).

2b. Houses with brick foundations and above-ground timber-framed parts

2b1. Timber-framed houses on stone and brick foundations

This group is characterised by the extensive multi-strip residential and utility buildings with a mixed timber-framed and stone structure, which are known from the archaeological research of the Sobótka location, where they appeared at the end of the Middle Ages and functioned until the $19^{\text {th }}$ century. The oldest of the wattle and daub buildings, which replaced the older still scattered dugouts, stood on foundations that were very carefully sealed with stone. In the younger phases, buildings were erected on stone foundations or with a mixed, stone and timber-framed wall structure. In the interiors, under the layer of half-timbered debris, both the dirt floor and fire layers with relics of the structure of wooden floors and timber-framed internal divisions, also protected with stone, were preserved (Fig. 6) (Limisiewicz, Mruczek 2001). The few remaining brick front houses near the Sobótka Market Square, representing similar spatial solutions and good-class examples of the late-Gothic architectural detail from the 1530s, suggest that this building action dates back to the late decades of the late Middle Ages. It is worth noticing that the adoption of this chronology of the increased construction traffic in small Silesian towns corresponds well with the origin of the oldest preserved timber-framed buildings in the suburban estates of Wrocław patricians and 
the construction of numerous wattle and daub churches in villages and suburbs near Wrocław. At the same time, it should be emphasised that this movement is only slightly ahead of the chronology of the oldest known buildings of this type in the Sudeten Foothills (Trocka-Leszczyńska 1995; Górska 2011).

\section{2b2.Timber-framed houses on arcade foundations (pillar-arch)}

A separate issue is the functioning of multi-storey timber-framed houses which were erected on pillar-arch, brick, brick-stone and stone foundations. The appearance of such solutions on a large scale in Wrocław and Głogów was usually connected with subsequent slightly later stages of the development of the bourgeois house, when the gradual increase in cultural layers covered the old ground floors of tenement houses, leading to their transformation into cellars (the turn of phases: IIa and IIb - around 1350; after Chorowska 1994). The three- to four-meter-thick sequences of unstable settlement layers undoubtedly posed a threat to the statics of the newly erected buildings, therefore, even for timber-framed layouts without cellars, solid arcaded foundations reaching up to sand layers were laid or their organised systems known as border (neighboring) walls. Good examples of such solutions are provided by the relics of the houses which were erected in the walled zone of the inner ring of Wrocław's fortifications. Among them, we should mention the layout with the archival address, i.e. 3 Zaułek Niski (Ger. Graben), which was situated at the end of the former Badergäßchen cul-de-sac on the plan of an elongated rectangle formed by late-medieval arcaded walls with a basement from the Renaissance period. Usually, however, pillars and arcades are characterised by less careful workmanship and limited durability. The pillars were usually built in narrow-space earthworks and the arcades were almost always modeled on earthen profiles. The builders behaved similarly in the case of the timber-framed Salwator Church in Przedmieście Świdnickie in Wrocław (phases I-V: 1561-1763), which was erected on a solid brick pillar-arch foundation in a wet area in the foreground of city fortifications (Fig. 7) (Guszpit et al 2015).

It was different in the case of Świdnica, where stoops were liquidated and the line of development of the market frontages was withdrawn. It was then that the complicated systems of pillar-arch foundations were used in phase II (1350-1530) to erect brick front houses in place of the liquidated timber-framed buildings. Of course, there was a problem of a collision with the brick cellar parts, which until then had been an independent self-supporting structure. Its solution required the introduction of massive pillars into the interior of older stone cellars and throwing - over the tops of their barrel vaults - very solid structural arcades in order to support the front walls of the newly erected tenement houses, which were shifted back to the back of the plots (Chorowska, Lasota 2013). 


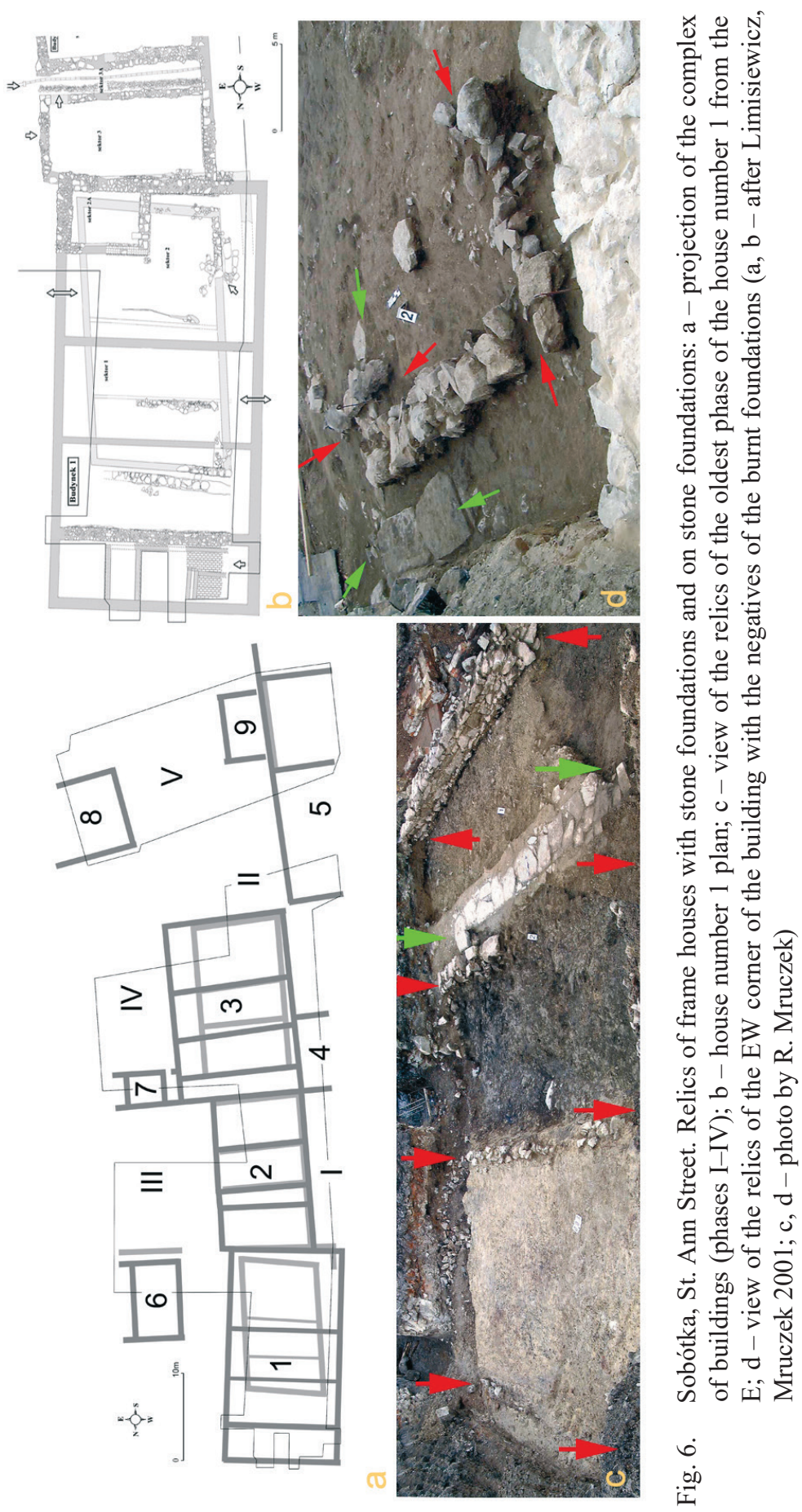



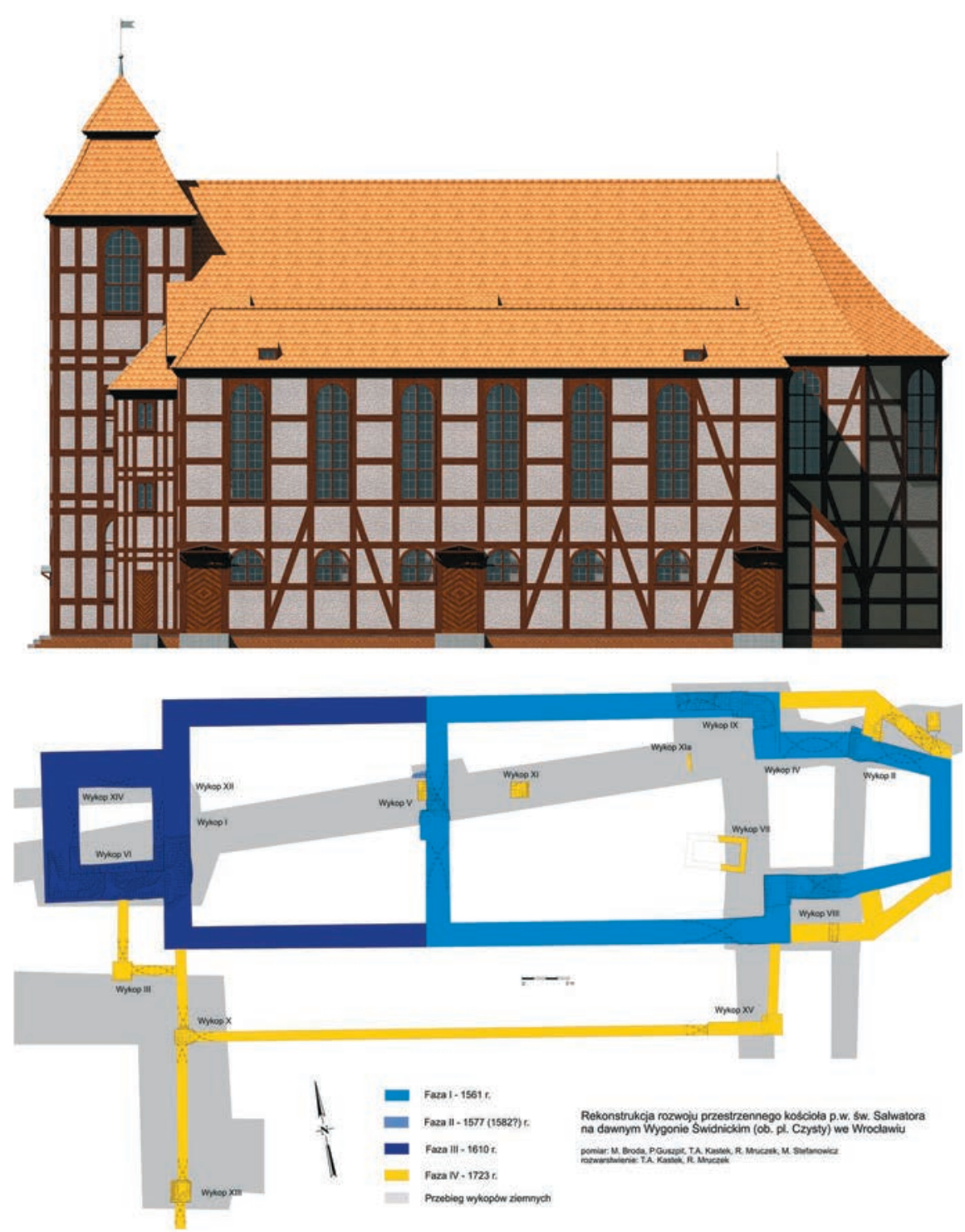

Fig. 7. Wrocław, Przedmieście Świdnickie (Ger. Schweidnitzer Anger), Czysty Square. Relics of the Salvator church (phases I-V: 1561-1763). An example of a frame structure built on a pillar-arch foundation (projection with chronological stratification - after Guszpit et al. 2015; reconstruction and 3D model of the church (phase V) - after Caban 2015) 
2c. Houses with a mixed structure of aboveground parts. This is another, probably formerly numerous and today hardly to find group of objects. It can be initially divided into:

2c1.houses of different structure of individual sections;

2c2 houses of different structure of individual stories;

2c3.houses with transverse timber-framed walls.

Variant I is represented, among other things, by two very characteristic and at the same time genetically different examples of Głogów Old Town buildings from phase II. The house at 9 Słodowa Street, which was erected as a result of an organised neighborly construction action, including layouts with numbers 6-10, had a classic two-section layout with an entryway with an annex, as well as a rear room and a walkway. The front section was built of brick, whereas the back section had a timber-framed structure until the $19^{\text {th }}$-century reconstruction. The homogeneity of this concept and the integrity of both sections are undeniably evidenced by transport openings which were originally modeled in the inter-section wall at the basement level and bore traces of use. It is worth noticing that the $19^{\text {th }}$-century remodeling constitutes in fact a repetition of the older layout of the back section, which was made of durable material (Burnita et al. 2000).

A different type was represented by the corner house mentioned in the title of the study at the intersection of Parafialna and 1 Garncarska Streets, which was also constructed in phase II. This, so far, completely unique object in the scale of Silesia, also had a two-section layout. The structure of the front section was based on a wooden frame, at the basement level, filled with bricks inside and covered with bricks in the Wendish bond on the external side. Initially, each wall had to have six-seven columns with a cross-section of $24-30 \mathrm{~cm}$, which were placed on a solid foundation and connected with a pile cap at the height of the cellar ceiling. The timber-framed structure was certainly continued in the upper stories. The back section with much thicker perimeter walls, which were built of the gothic bond and devoid of a wooden frame, was probably entirely made of brick. It is quite possible that a little higher than the front one, it towered above it like Steinwerk. The significant distance of the front wall of the building from the development line and the collapse of its ridge wall indicate the presence of arcades (Mruczek, Stefanowicz 2007; Mruczek 2010, pp. 178-179, Fig. XIII; 2019a, pp. 59-60, Fig. 4). This chronologically homogeneous, though technologically diverse building was probably not the only object of this type in the town, however, the chances of discovering a similar structure are slim. Its survival in the archaeological layers was determined by accident - the Baroque remodeling resulted in the complete abandonment and filling of the front basement and the erection of a house with a different layout, partially without a basement.

Variant II is currently the most difficult to analyse not only due to the complete remodeling of Wrocław houses and destruction of Głogów houses in the post-war 
period but since there are also no archival materials regarding the condition of tenement houses before 1945. Therefore, our conclusions can be based on indirect premises and Silesian analogies only. Usually, the structure and width of the perimeter, inter-section, and other walls, strengthened in subsequent stages of house extensions, especially in phase II, were taken into consideration. However, this is an unreliable criterion.

Variant III includes houses which were erected in the system of brick neighboring (border) walls with load-bearing character, whose transverse walls, i.e. front, inter-section and back, were made in the timber-framed structure as screen walls. We can guess their existence wherever the transverse walls mentioned above had an 'economical' arcaded structure and a small width at the basement level. This applies, for example, to the complex of houses in the central part of the western frontage of Kotlarska Street, numbers 1a and 1-2 (quarter A15/A16) (Fig. 8). This difference is particularly striking in comparison with, for example, houses at 5-6 Długa Street (square A10) or a complex of houses at 7-10 Słodowa Street from phase II, undoubtedly with brick fronts. The analysis of individual transverse walls of cellars in twin houses at 5-6 Długa Street (square A10; phase II) also makes it possible - in the context of the ground floor plan - to divide them into 'load-bearing' and 'non-bearing'. The analysis of the inter-section walls in very early houses in Parafialna Street (phase I) may also be surprising. The corner tenement house (number 1), at the intersection with Balwierska Street (square A23), three-section at the basement level, turns into a two-section layout on the ground floor, as evidenced by the ceramic floors of the entryway, which are fragmentarily preserved on the crown of the more massive wall (Mruczek, Stefanowicz 2007; 2008).

During the research on the tenement house at 5 Kotlarska Street (quarter A15/ A16), a rare and well documented record of a construction disaster (catastrophic collapse) was found (Fig. 8). As a result, the timber-framed back gable wall was replaced with a brick one. Poor binding parameters of the mortar and improper foundation resulted in quick subsidence and significant deviation from the vertical of the wall towards the back part of the plot. The measures taken by the owner, which consisted in building a new back wall located within the basement - on the extension of both gable neighboring walls, constituting a resistance (in the form of a shield wall) to the endangered barrel vault, prove that the older one was finally pulled down or collapsed. 


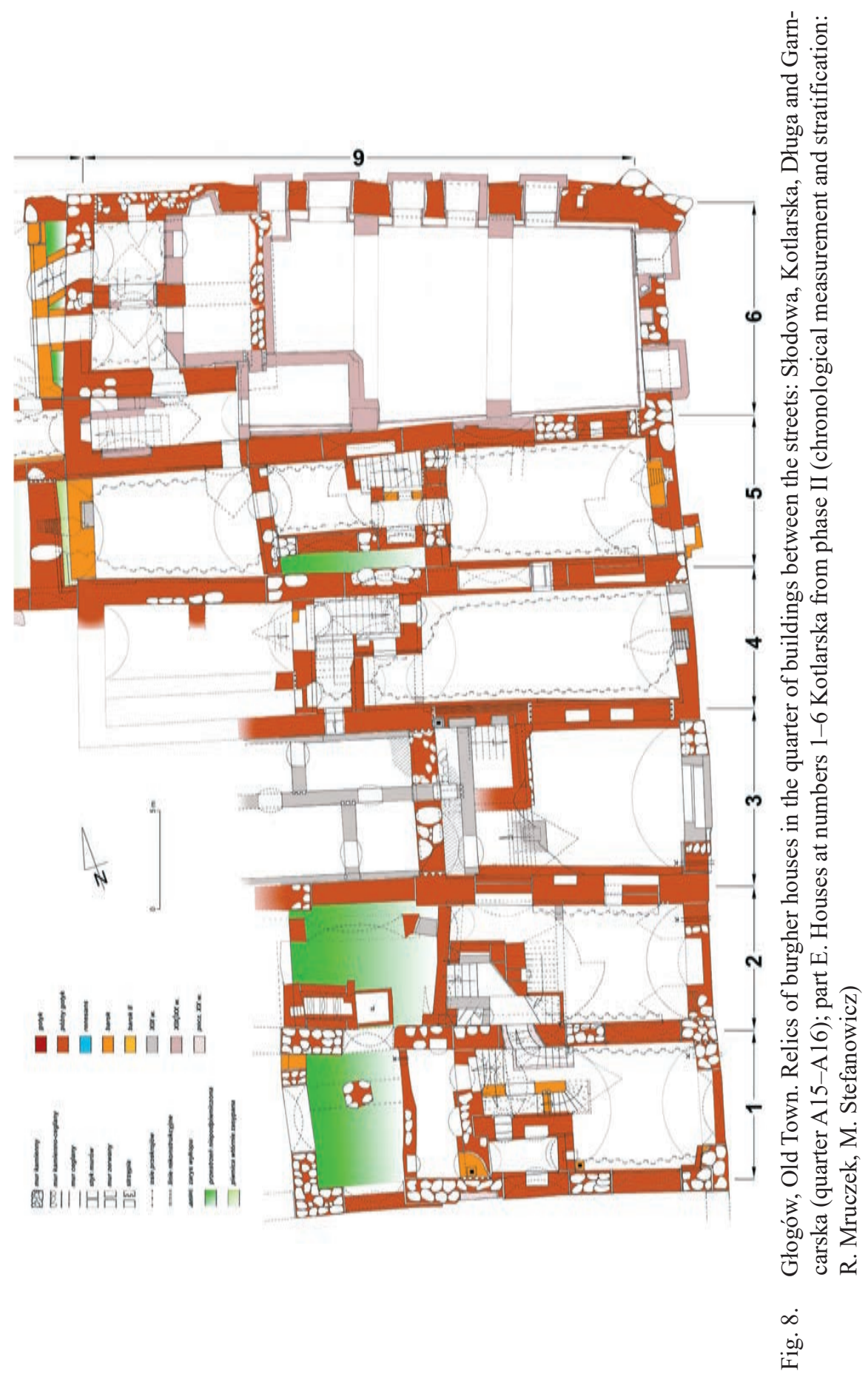




\section{Summary}

A huge variety of the structural solutions of medieval town houses in Silesia, which was presented above - constituting in a sense some contrast for its unattainable model - also in the technical and technological meaning - which is a burgher tenement house in Wrocław (Fig. 9), is a derivative of many individual factors

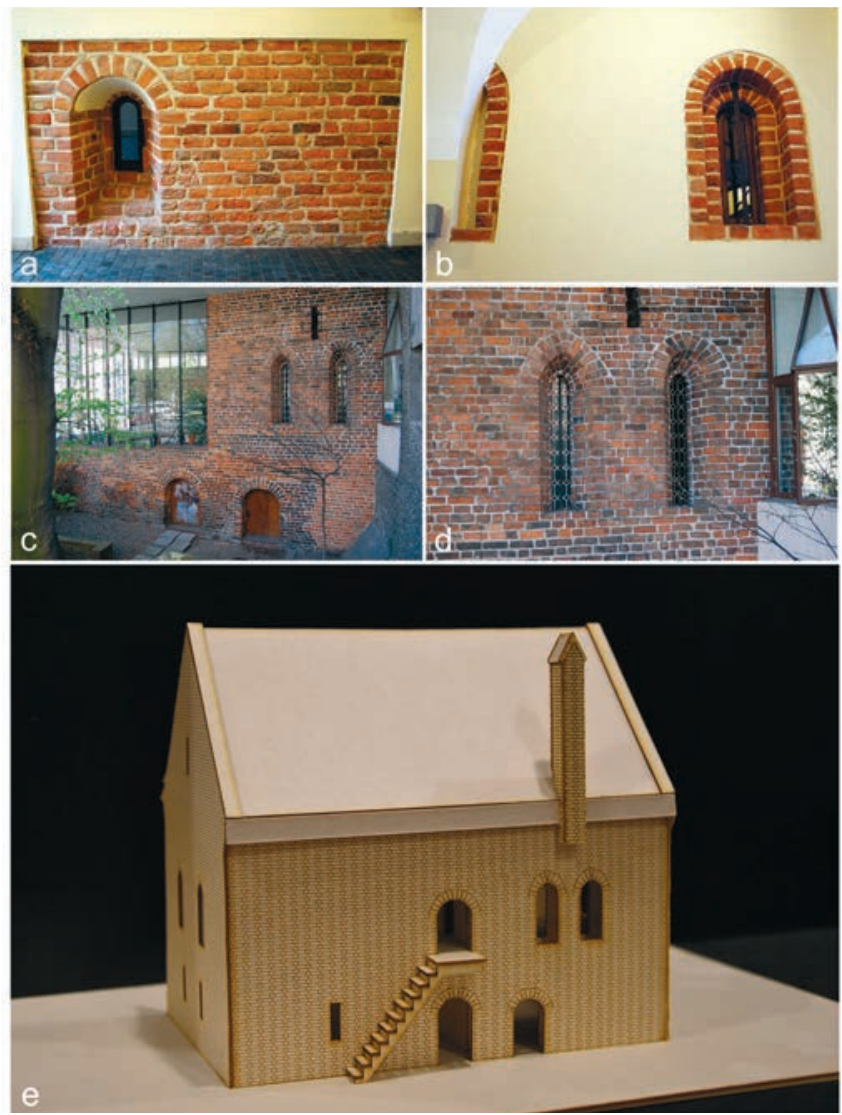

Fig. 9. Wrocław, Old Town. Bourgeois tenement houses from the $13^{\text {th }}$ century: a - tenement house at Rynek 6; window II. of the storey at the rear of the northern house $\left(13^{\text {th }}\right.$ century), exposed in the vestibule of a contemporary tenement house; $b$ - windows III. of the storey of the rear wing in the southern house $\left(13^{\text {th }}\right.$ century), visible in the entrance hall of a contemporary tenement house; $\mathrm{c}$ - the so-called Dom Panien Trzebnickich (Trzebnickie Maidens House) at 8 Biskupa Nankera Place; western elevation; d - close-up of the first floor window openings ( $2^{\text {nd }}$ quarter of the $13^{\text {th }}$ century); e $-3 \mathrm{D}$ model; student work (photo by R. Mruczek) 
which contributed to the emergence and development of the early urban centres of the region. In order to understand the phenomenon of the Wrocław house, setting the limit of ambitions and financial possibilities of the investors at that time, one must know that the key factor is certainly the long and confirmed by sources from the turn of the $13^{\text {th }}$ century presence of foreign guests in the early city agglomeration - Jews, Walloons and Germans as well as local wealthy feudal lords from the prince's or church hierarchs' entourage (Piekalski 2014, pp. 160-162). In the capital city of Silesia - located near Via Regia and the main Odra crossing - advanced western timber-framed structures and fully masonry structures appeared at a similar time at the beginning of the $13^{\text {th }}$ century and the current overrepresentation of the latter is the result of the displacement of post and timber as well as timber buildings with horizontal beams, and almost complete destruction of its archaeological evidence during the process of constructing front houses with basements still in the late Middle Ages. The resulting stratigraphic gap distorts the image of the early town houses. The famous Świdnica Old Town horizon of bourgeois houses which consist of detached brick basement under timber-framed buildings (1250-1380) - is not represented in large numbers in Wrocław, although it probably brings the oldest structures of this type in Silesia, dating back already to the $2^{\text {nd }}$ quarter of the $13^{\text {th }}$ century. An alternative solution - a house with a mixed brick-timber-framed structure with Steinwerk - although known only in a single copy from the Old Town in Głogów, requires special attention from researchers as an alleged lost link in the development of a medieval town house in Silesia. The use of brick filling in timber framing structures is highly probable, as evidenced by the $13^{\text {th }}$-century archaeological layers with brick debris, which were discovered within the Old Town bourgeois plots.

\section{References}

Abbreviations

SSA - Śląskie Sprawozdania Archeologiczne, Wrocław

Boguszewicz A., 2010, Corona Silesiae. Zamki Piastów fürstenberskich na potudniowym pograniczu księstwa jaworskiego, świdnickiego i ziębickiego do połowy XIV wieku, Wrocław.

Burnita J., Lasota C., Mruczek R., 2000, Badania architektoniczne w obrębie parcel położonych w południowej części kwartału zabudowy ograniczonego ulicami: Słodową, Kotlarską i Garncarską (A15 i A16) w Głogowie, typescript in the archive of Provincial Monument Coservator (Wojewódzki Urząd Ochrony Zabytków) in Wrocław, Branch Office in Legnica (Delegatura w Legnicy), Wrocław. 
Caban M., 2015, Kościót Salwatora we Wrocławiu. Rekonstrukcja kościoła Salwatora we Wrocławiu, [in:] Cmentarz Salwatora. Pierwsza nekropola wrocławskich protestantów, ed. K. Wachowski, Wratislavia Antiqua, 21, Wrocław, pp. 175-190.

Chorowska M., 1994, Średniowieczna kamienica mieszczańska we Wrocławiu, Wrocław.

Chorowska M., 2003, Rezydencje średniowieczne na Śląsku. Zamki, pałace wieże mieszkalne, Wrocław.

Chorowska M., 2010a, Od szachulców do kamienic. Etapy ksztaltowania się średniowiecznej zabudowy mieszkalnej w Świdnicy na przyktadzie zachodniej pierzei Rynkowej, [in:] Non solum villae. Ksiega jubileuszowa ofiarowana profesorowi Stanistawowi Medekszy, ed. J. Kościuk, Wrocław, pp. 347-360.

Chorowska M., 2010b, Pałac i kamienica. Wpływ siedziby pańskiej na wrocławskie i podwrockawskie domy mieszczan w średniowieczu, [in:] Dom, majątek, klient, stuga. Manifestacja pozycji elit w przestrzeni materialnej i spotecznej (XIII-XIX w.), eds. M.R. Pauk, M. Saczyńska, Warszawa, pp. 63-80.

Chorowska M., 2011, Średniowieczne domy mieszkalne, [w:] Leksykon architektury Wrocławia, eds. R. Eysymontt, J. Ilkosz, A. Tomaszewicz, J. Urbanik, Wrocław, pp. 49-54.

Chorowska M., Błoniewski P., 2013, Zamek Niesytno w Płoninie wedlug badań architektonicznych z lat 2011-2012, Architectus, 2(34), pp. 4-16.

Chorowska M., Konczewski P., Lasota C., Piekalski J., 2012, Parcela Rynek 6-ul. Kietbaśnicza 5 we Wrocławiu. Rozwój zabudowy i infrastruktury elitarnej działki mieszczańskiej w XIII-XIV wieku, SSA, vol. 54, pp. 49-77.

Chorowska M., Kwaśniewski A., 2000, Wyprzedzające, interdyscyplinarne badania archeologiczno-architektoniczne w obrębie placu Dominikańskiego we Wrocławiu. Wyniki badań architektonicznych, typescript in archive Wojewódzki Urząd Ochrony Zabytków (Provincial Monument Coservator) in Wrocław, Wrocław.

Chorowska M., Lasota C., 2003, Kamienice w Świdnicy do początku XVII wieku, [in:] Dziedzictwo artystyczne Świdnicy, ed. B. Czechowicz, Wrocław-Świdnica, pp. 41-65.

Chorowska M., Lasota C., 2013, Kamienica mieszczańska w Świdnicy: karczma i mieszkanie w XIII-XVIII w., Wrocław.

Ciara G., Mruczek R., Stefanowicz M., 2003, Z badań architektury Starego Miasta w Polkowicach w roku 2001, SSA, vol. 45, pp. 207-217.

Gliński R., 2013, Średniowieczny i wczesnonowożytny dom mieszczański w matym i średniej wielkości mieście śląskim - zarys problematyki badawczej, Quart, 4(30), pp. 3-19.

Górska H., 2011, Dwory i pałace szkieletowe w Polsce, Wrocław.

Guszpit P., Mruczek R., Kastek T. A., 2015, Kościól Salwatora we Wrocławiu. Relikty kościola Salwatora we Wrocławiu, [in:] Cmentarz Salwatora. Pierwsza nekropola wrocławskich protestantów, ed. K. Wachowski, Wratislavia Antiqua, 21, Wrocław, pp. 163-175.

Guszpit P., Mruczek R., Piekalski J., 2002, Środa Ślaska. Zaplecze targu małego miasta średniowiecznego, SSA, vol. 44, pp. 431-448.

Jaworski K., 1999, Późnośredniowieczne budownictwo drewniane we Wrocławiu, Mediaevalia Archaeologica Bohemica, vol. 2, pp. 54-83. 
Kaźmierczyk J., 1966, Wrocław lewobrzeżny we wczesnym średniowieczu, 1, Wrocław.

Kaźmierczyk J., 1970, Wrocław lewobrzeżny we wczesnym średniowieczu, 2, Wrocław.

Kaźmierczyk J., 1991, Ku początkom Wrocławia, part 1: Warsztat budowlany i kultura mieszkalna Ostrowa Tumskiego od X do połowy XI wieku, Wrocław.

Kaźmierczyk J., 1993, Ku początkom Wrocławia, part 2: Warsztat budowlany i kultura mieszkalna Ostrowa Tumskiego od połowy XI do połowy XIII wieku, Wrocław.

Kaźmierczyk J., 1995, Ku początkom Wrocławia, part 3: Gród na Ostrowie Tumskim w X-XIII wieku, Wrocław.

Kąsinowski A., 1992, Ein Blick auf die mittelalterliche Raumdisposition von Elbing und ihre Realisierung: Stadt-Baumkomplex-Bauparzelle, [in:] Archaeologia Elbingensis, vol. 1: Elbląg - nowe spojrzenie na średniowieczne miasto, eds. A. Czacharowski, T. Nawrolski, Gdańsk, pp. 67-78.

Kitliński B., 2002, Badania przy wschodniej pierzei Rynku, [in:] Rynek wrocławski w świetle badań archeologicznych, part 2, ed. J. Piekalski, Wratislavia Antiqua, 5, Wrocław, pp. 173-181.

Kozaczewski T., 2006, Głogów średniowieczny do końca XIII w. Osadnictwo i architektura, Głogów.

Kozak S., Steinborn B., 1971, Ztotoryja - Chojnów - Świerzawa, Wrocław.

Krzywka Ł., 2000, Kamienice Rynek 33 i Kurzy Targ 6-8. Zagadnienia konserwatorskie, Renowacje, no. 2(12), pp. 34-62.

Limisiewicz A., Mruczek R., 2001, Ratownicze badania archeologiczno-architektoniczne na terenie dawnego folwarku przy Alei św. Anny w Sobótce w 2000 r., SSA, vol. 43, pp. 373-384.

Limisiewicz A., Mruczek R., 2010, Fara św. Marii Magdaleny na tle przemian przestrzennych wczesnego Wrocławia. [in:] Śródmiejska Katedra: kościót św. Marii Magdaleny w dziejach i kulturze Wrocławia, ed. B. Czechowicz, Wrocław, pp. 55-136.

Mruczek R., 2000, Kurzy Targ we Wroctawiu. Uwagi o pierwotnym planie miasta, [in:] Centrum średniowiecznego miasta. Wrocław a Europa środkowa, eds. J. Piekalski, K. Wachowski, Wratislavia Antiqua, 2, Wrocław, pp. 259-278.

Mruczek R., 2005, Wieloboczny bergfried zamku we Wleniu na tle architektury ślaskiej i europejskiej, [in:] Nie tylko zamki, Szkice ofiarowane Profesorowi Jerzemu Rozpędowskiemu w siedemdziesiąta piąta rocznicę urodzin, eds. E. Różycka, M. Chorowska, Wrocław, pp. 55-71;

Mruczek R., 2010, Średniowieczna i wczesnonowożytna architektura Starego Miasta w Gtogowie w świetle nowszych badań, [in:] Glogovia Maior: Wielki Głogów między blaskiem dziejów i cieniem ruin, eds. B. Czechowicz, M. Konopnicka, Głogów, pp. 139-181.

Mruczek R., 2018, Bergfried, Donjon, Eigenkirche. Miejsce zamków śląskich w architekturze europejskiej, Archaeologia Historica Polona, vol. 26, pp. 99-132.

Mruczek R., 2019a, Średniowieczne miasto lokacyjne na Śląsku. Kamienice, wieże mieszkalne $i$ konstrukcje ulic, [in:] Dziedzictwo architektoniczne. W kręgu świata przyrodniczego i budowli miejskich, ed. E. Łużyniecka, Wrocław, pp. 55-73. 
Mruczek R., 2019b, Archeologia architektury Wroctawia: metody nieinwazyjne w badaniach nad warsztatem budowlanym przełomu średniowiecza i nowożytności, Archaeologia Historica Polona, vol. 27, pp. 181-217.

Mruczek R., Stefanowicz M., 2007, Z badań kamienicy mieszczańskiej w Głogowie, SSA, vol. 49, pp. 265-286.

Mruczek R., Stefanowicz M., 2008, Z badań architektury Starego Miasta w Gtogowie. cz. 1. Relikty kamienic mieszczańskich u zbiegu ulic Parafialnej i Balwierskiej, SSA, vol. 50, pp. 259-292.

Mruczek R., Stefanowicz M., 2010, Poludniowy pas obwarowań i fortyfikacji Wroctawia $w$ rejonie obecnego $\mathrm{Pl}$. Wolności na tle przemian przestrzennych i prawnych miasta średniowiecznego i nowożytnego, [in:] Non solum villae. Księga jubileuszowa ofiarowana profesorowi Stanisławowi Medekszy, ed. J. Kościuk, Wrocław, pp. 401-454.

Niegoda J., 2005, Zmiany w zagospodarowaniu przestrzeni w rejonie placu Nowy Targ w XIIXIV w., [in:] Wschodnia strefa Starego Miasta we Wrocławiu w XII-XIV wieku. Badania na placu Nowy Targ, ed. C. Buśko, Wrocław, pp. 69-84.

Piekalski J., 1995, Ze studiów nad drewniana zabudowa Wrocławia w późnym średniowieczu, [in:] Architektura Wrocławia, vol. 1: Dom, ed. J. Rozpędowski, Wrocław, pp. $75-87$.

Piekalski J., 1996, Z badań drewnianej zabudowy średniowiecznej działki mieszczańskiej na Śląsu, Historii Kultury Materialnej, 44(1), pp. 5-12.

Piekalski J., 2004, Wczesne domy mieszczan w Europie Środkowej, Wrocław.

Piekalski J., 2014, Praga, Wrocław, Kraków. Przestrzeń publiczna i prywatna w czasach średniowiecznego przełomu, Wrocław.

Polak Z., Rębkowski M., 1996, Budownictwo i architektura, [w:] Archeologia średniowiecznego Kołobrzegu, vol. 1: Badania przy ul. Ratuszowej 9-13, ed. M. Rębkowski, Kołobrzeg, pp. 209-220.

Rynek wrocławski 1, 2001, Rynek wrocławski w świetle badań archeologicznych, part 1, ed. C. Buśko, Wratislavia Antiqua, 3, Wrocław.

Rynek wrocławski 2, 2002, Rynek wrocławski wświetle badań archeologicznych, part 2, ed. J. Piekalski, Wratislavia Antiqua, 5, Wrocław.

Trocka-Leszczyńska E. 1995, Wiejska zabudowa mieszkaniowa w regionie sudeckim, Wrocław. 